\title{
OPEN Using stable isotopes to analyse extinction risks and reintroduction opportunities of native species in invaded ecosystems
}

\author{
Phillip J. Haubrock ${ }^{1,2 \bowtie}$, Paride Balzani ${ }^{3}$, J. Robert Britton ${ }^{4}$ \& Peter Haase ${ }^{1,5}$
}

Invasive non-native species have pervasive impacts on native biodiversity, including population extirpations and species extinctions. Identifying reasons why a population of a native species is extirpated following an invasion often relies on literature-based results of anecdotal observations. The well-established schemes of existing risk assessments for invasive species assume that a species' information (e.g. impacts or behavioural and biological traits) can be projected from one area to another to estimate the potential impact of a species in another environment. We used stable isotope data $\left(\delta^{13} \mathrm{C}, \delta^{15} \mathrm{~N}\right)$ from both invaded and uninvaded communities to predict such invasion impacts by reconstructing trophic relationships. This approach was tested on a community within a protected lake in Northern Spain where, following the introductions of non-native species, the last resident native species (the common tench Tinca tinca, the European eel Anguilla anguilla, and the whirligig beetle Gyrinus sp.) had been extirpated. Through the application of this novel approach, we found evidence that native species' declines were related to direct predation by and resource overlap with non-native species, which occurred in conjunction with habitat modification. Using this approach, we outlined the mechanisms involved in the extirpation of native species in the post-invasion period. To compensate for losses of native species induced by invasions of non-native species, native species reintroductions might be an appropriate tool. For this, we further suggested and discussed a novel approach that predicts the outcome of arising interactions by superimposing stable isotope data from alternative sources to better estimate the success of native species' reintroductions.

The ecological consequences of aquatic invasions have gained substantial attention in recent decades ${ }^{1,2}$. Whilst previous research has addressed species-specific invader impacts on native species ${ }^{3-5}$, ecosystems ${ }^{6,7}$, ecosystem services $^{8}$ or mechanisms underlying invasions ${ }^{9-11}$, attention is now shifting towards impacts on entire communities and complex species interactions ${ }^{6,12-14}$.

In the management of aquatic invasions, tools commonly applied to prevent species introductions include the development and application of risk assessment tools ${ }^{15-17}$. These are usually reliant on extrapolating data from a species' native range or from other introduced populations to identify potential threats and ecological impacts that would arise in a new area ${ }^{18,19}$. Alternative techniques to predict impacts using modelling ${ }^{20}$ or experimental approaches ${ }^{21-23}$ have also been proposed. However, the extent to which these approaches can scale up to predict impacts in more complex systems can have high context dependency ${ }^{24,25}$. More recent methods, such as stable isotope analysis $\left(\mathrm{SIA}^{26}\right.$ ), provide new possibilities to investigate aquatic invasion risks and their associated impacts. This is especially pertinent in invaded communities where there is a high level of complexity in species interactions, which in turn could potentially lead to novel, but often less conspicuous impacts on native species and aspects of their habitats ${ }^{27,28}$.

\footnotetext{
${ }^{1}$ Department of River Ecology and Conservation, Senckenberg Research Institute and Natural History Museum Frankfurt, Clamecystrasse 12, 63571 Gelnhausen, Germany. ${ }^{2}$ Faculty of Fisheries and Protection of Waters, CENAKVA, University of South Bohemia in České Budějovice, Vodňany, Czechia. ${ }^{3}$ Department of Biology, University of Florence, Via Madonna del Piano 6, 50019 Florence, Italy. ${ }^{4}$ Department of Life and Environmental Sciences, Faculty of Science and Technology, Bournemouth University, Poole, Dorset, UK. ${ }^{5}$ Faculty of Biology, University of Duisburg-Essen, 45141 Essen, Germany. ${ }^{6}$ These authors contributed equally: Phillip J. Haubrock and Paride Balzani. ${ }^{\square}$ email: Phillip.Haubrock@Senckenberg.de
} 


\begin{tabular}{|c|c|c|c|c|}
\hline Group & Species & First detected & Reference & Pathways \\
\hline \multicolumn{5}{|c|}{ Non-native species } \\
\hline \multirow{3}{*}{ Fish } & Micropterus salmoides & 1994 & 39 & \multirow{3}{*}{ Angling } \\
\hline & Lepomis gibbosus & 2005 & 38 & \\
\hline & Cyprinus carpio & 2010 & 38 & \\
\hline Crayfish & Procambarus clarkii & 1998 & 38 & Aquaculture \\
\hline \multirow{2}{*}{ Plants } & Phragmites australis & 1998 & 5 & \multirow{2}{*}{ Unknown } \\
\hline & Cladium mariscus & 1998 & 5 & \\
\hline Group & Species & Extirpation date & Reference & Pathways \\
\hline \multicolumn{5}{|c|}{ Native species } \\
\hline \multirow{2}{*}{ Fish } & Anguilla anguilla & 2000 & 5 & Not applicable \\
\hline & Tinca tinca & 2013 & 5 & Not applicable \\
\hline Crayfish & Austropotamobius pallipes & 2014 & 5 & Not applicable \\
\hline Insects & Gyrinus sp. & 2008 & 5 & Not applicable \\
\hline
\end{tabular}

Table 1. Non-native species present in Arreo Lake, showing the year of its first detection and the most likely pathway.

Stable isotope analyses (SIA) provide long-term and time-mediated information on consumed trophic resource $s^{29,30}$ and are used to describe quantitatively the trophic relationships occurring among organisms, highlighting potential diet overlap and feeding competition between species ${ }^{31}$ and estimating the proportion of different preys in the diet ${ }^{32}$. Accordingly, it can be used to investigate the impact of invasive species on native ones $s^{4,26}$ and on local communities ${ }^{27,33}$. SIA is based on predictable changes in nitrogen $\left(\delta^{15} \mathrm{~N}\right)$ and carbon $\left(\delta^{13} \mathrm{C}\right)$ isotope ratios between consumers and their food sources ${ }^{34}: \delta^{15} \mathrm{~N}$ indicates the trophic position within a food web, while $\delta^{13} \mathrm{C}$ identifies major energy sources. Following the common practice of risk assessments ${ }^{19}$ extrapolating species information from one region onto another ${ }^{15-17}$, we suggest that stable isotopes can be used in a similar fashion.

To test the suitability of stable isotope analysis to better understand invasive species' impacts on native communities, a simplified study system is required, such as the invaded community of Arreo Lake (Spain). Prior to 1990, various taxa of native fish and invertebrates were present in Arreo Lake; however, they are now considered extirpated or locally extinct ${ }^{5}$. Among these, some are of regional concern: the European eel Anguilla anguilla LiNNAEUs, 1758 (considered extirpated after 2000), the endemic whirligig beetles Gyrinus sp. GEOFFrEOY, 1762 (considered extirpated after 2008), the common tench Tinca tinca LinNAEUs, 1758 (considered extirpated after 2013), and the white-claw crayfish Austropotamobius pallipes Lereboullet, 1858 (considered extirpated after 2014). Moreover, A. anguilla and A. pallipes are both included in the IUCN red list risk categories as "critically endangered" and "endangered", respectively ${ }^{35,36}$. These extirpations were mainly attributed to subsequent introductions of various non-native species which out-competed or predated native species ${ }^{37,38}$. The protected area of Arreo Lake was not utilized for angling nor changed in terms of water quality 33,38 , but non-native fish and crayfish species introductions likely relate to introductions from illegal anglers or the live-bait pathway (Table 1). The resultant non-native species community is characterised by high linkage density and connectance in the foodweb due to its strong trophic interactions and predator-prey relationships ${ }^{5,33}$. In particular, in the last decade, the community and habitat of Arreo Lake has substantially changed through the loss of native fishes and macrophytes. Particularly the presence of the crayfish Procambarus clarkii has led to disruptions of the habitat and the native flora, leading to the dominance of Phragmites australis and Cladium mariscus; both non-native plants ${ }^{5}$.

As control efforts in Arreo Lake failed to eradicate non-native species and to restore populations of native species, new possibilities to control the non-native species have been investigated. Haubrock et al. ${ }^{33}$ explored the effectiveness of reintroducing a once native predator, the European eel Anguilla anguilla (LinnAEus, 1758) as a bio-control agent by combining standardized stable isotope data from two sources (i.e. the target community Arreo Lake and the target species A. anguilla from a German Lake), dietary analyses and literature reviews. As a result, that particular study highlighted that the reintroduction of eels could affect species in lower trophic positions, while the eel itself could potentially be preyed upon by the introduced top predator Micropterus salmoides, limiting the efficacy of this management effort.

In Arreo Lake, as well as many other aquatic ecosystems, the exact causes of native species population extirpations have not yet been fully identified, preventing the design and implementation of appropriate restoration actions. To address this, the aim of our study was to develop and present a new methodological approach that projects stable isotope data onto the isotopic relationships of a focal community. Such an approach could potentially be used in two different scenarios:

(a) It could be applied retrospectively to reconstruct impacts of non-native species on extinct native species, with some caveats regarding uncertainties. Thus, by theoretically introducing stable isotope data from a species present in community A into community B where it is extinct, this approach could help understand the extent to which non-native species were responsible for these extinction of native species versus other possible explanations (e.g. changes in the abiotic components), and the mechanisms involved (e.g. predation or the adverse effects of increased inter-specific competition). 


\begin{tabular}{|c|c|c|c|c|c|c|c|c|c|}
\hline Species & $\begin{array}{l}\text { Trophic } \\
\text { position }\end{array}$ & $\begin{array}{l}\text { Nitrogen } \\
\text { range } \\
{\left[\delta^{15} \mathrm{~N}\right]}\end{array}$ & $\begin{array}{l}\text { Carbon } \\
\text { range } \\
{\left[\delta^{13} \mathrm{C}\right]}\end{array}$ & $\begin{array}{l}\text { Total hill } \\
\text { area }\end{array}$ & CD & NND & SDNND & SEAc & SEAb \\
\hline \multicolumn{10}{|l|}{ Communities } \\
\hline Community ${ }^{* * * *}$ & - & 9.6 & 12.3 & 53.78 & 3.19 & 0.43 & 0.35 & - & \\
\hline Community_T $T^{*}$ & - & 14.6 & 12.3 & 53.78 & 2.52 & 0.34 & 0.31 & - & \\
\hline Community_G** & - & 14.1 & 12.3 & 104.41 & 4.65 & 0.46 & 0.39 & - & \\
\hline Community_A $A^{* * *}$ & - & 14.1 & 12.3 & 106.08 & 4.07 & 0.36 & 0.32 & - & \\
\hline \multicolumn{10}{|l|}{ Non-native species } \\
\hline M. salmoides & 4.0 & 2.3 & 2.2 & 2.50 & 0.91 & 0.31 & 0.17 & 1.25 & 7.49 \\
\hline L. gibbosus & 3.5 & 3.8 & 3.3 & 4.95 & 1.19 & 0.48 & 0.43 & 2.23 & 13.35 \\
\hline C. carpio & 3.1 & 2.9 & 3.6 & 5.1 & 1.04 & 0.54 & 0.49 & 2.42 & 14.52 \\
\hline P. clarkii & 2.3 & 4.8 & 8.3 & 16.15 & 3.07 & 0.63 & 0.41 & 10.17 & 60.95 \\
\hline P. australis & Baseline & 1.0 & 1.4 & 0.11 & 0.56 & 0.33 & 0.17 & 0.14 & 0.84 \\
\hline \multicolumn{10}{|l|}{ Native species } \\
\hline T. tinca & 3.4 & 1.5 & 3.1 & 2.98 & 0.82 & 0.22 & 0.20 & 3.85 & 23.08 \\
\hline Gyrinus sp. & 2.1 & 2.3 & 7.2 & 9.44 & 1.50 & 0.57 & 0.49 & 0.89 & 5.33 \\
\hline A. anguilla & 3.8 & 3.1 & 3.3 & 7.50 & 1.03 & 0.25 & 0.17 & 1.98 & 11.88 \\
\hline
\end{tabular}

Table 2. Layman metrics for all species and the assumed present T. tinca, Gyrinus sp., and A. anguilla as well as the community with and without them. CD mean distance to centroid, NND mean nearest neighbour distance, SDNND standard deviation of the nearest neighbour distance, SEAc corrected Standard Ellipse Area considering $40 \%$ data coverage, SEA $b$ corrected Standard Ellipse Area considering $95 \%$ data coverage. ${ }^{*}$ Under consideration of T. tinca being present in Arreo Lake. ${ }^{* *}$ Under consideration of Gyrinus sp. being present in Arreo Lake. ${ }^{* *}$ Under consideration of $A$. anguilla being present in Arreo Lake. ${ }^{* * *}$ Under consideration of neither T. tinca nor Gyrinus sp. being present in Arreo Lake.

(b) It could also be used to predict potentially arising interactions (competition, predation, etc.) to eventually evaluate the extinction risk of native species in invaded ecosystems or ecosystems at risk of being invaded. This includes a new option for water managers to use this approach to better predict reintroduction success of native species in invaded ecosystems.

The simplicity of the current non-native species community in Arreo Lake provides an ideal model system for the described approach of using foreign stable isotope data (i.e. from a different community) from once native but today extirpated species with the aim of investigating possible reasons of extirpations and the probability of successful reintroduction attempts. The results obtained from this novel methodological approach will lay the groundwork for future studies utilizing stable isotopes in explanatory ways to depict antecedent and prospective species interactions.

\section{Results}

The inclusion of T. tinca within the species community had the effect of decreasing the trophic distance among the species while not increasing the overall niche area (see CD and NND; Table 2). The inclusion of Gyrinus sp. and A. anguilla, however, led to a substantial increase in the community's isotopic niche area (Table 2). The isotopic niche of T. tinca was small compared with other fish species. Yet, T. tinca occupied a higher trophic position than the non-native C. carpio, its closest ecological analogue in the lake (Table 2; Fig. 1). Anguilla anguilla occupied a predatory position, expressing an isotopic niche similar to those of L. gibbosus and M. salmoides. Conversely, Gyrinus sp. was predicted to occupy the lowest trophic position of all investigated species, whilst also having a relatively large isotopic niche (Table 2; Fig. 1). However, the carbon range of the non-native macroinvertebrate P. clarkii was greater than for Gyrinus sp., while T. tinca expressed a lower carbon range than C. carpio (Table 2).

The predicted and actual isotopic niches (as SEAb) of the species in the lake revealed that when T. tinca was included in the analyses, shared dietary resources overlap would occur with L. gibbosus and P. clarkii, but also partially with C. carpio (Fig. 1; Table 3). It was also estimated that $M$. salmoides would occupy a distinct isotopic niche to T. tinca and was positioned higher in the food web (Fig. 1; Table 2). In contrast to T. tinca, A. anguilla expressed high overlap with L. gibbosus and C. carpio while Gyrinus sp. was projected to occupy a distinct isotopic niche at a low position in the food web (Fig. 1). It did not share isotopic space with any other species nor did it express the potential to occur within another species isotopic niche (Table 3 ). The applied mixing models predicted that, based on these isotopic values, $M$. salmoides had a relatively high probability of predating on $T$. tinca (Fig ure 2a), but not on A. anguilla (Fig. 2b). For Gyrinus sp., the mixing models predicted that neither $L$. gibbosus nor P. clarkii expressed the likeliness to be an active predator (Fig. 2c,d). 


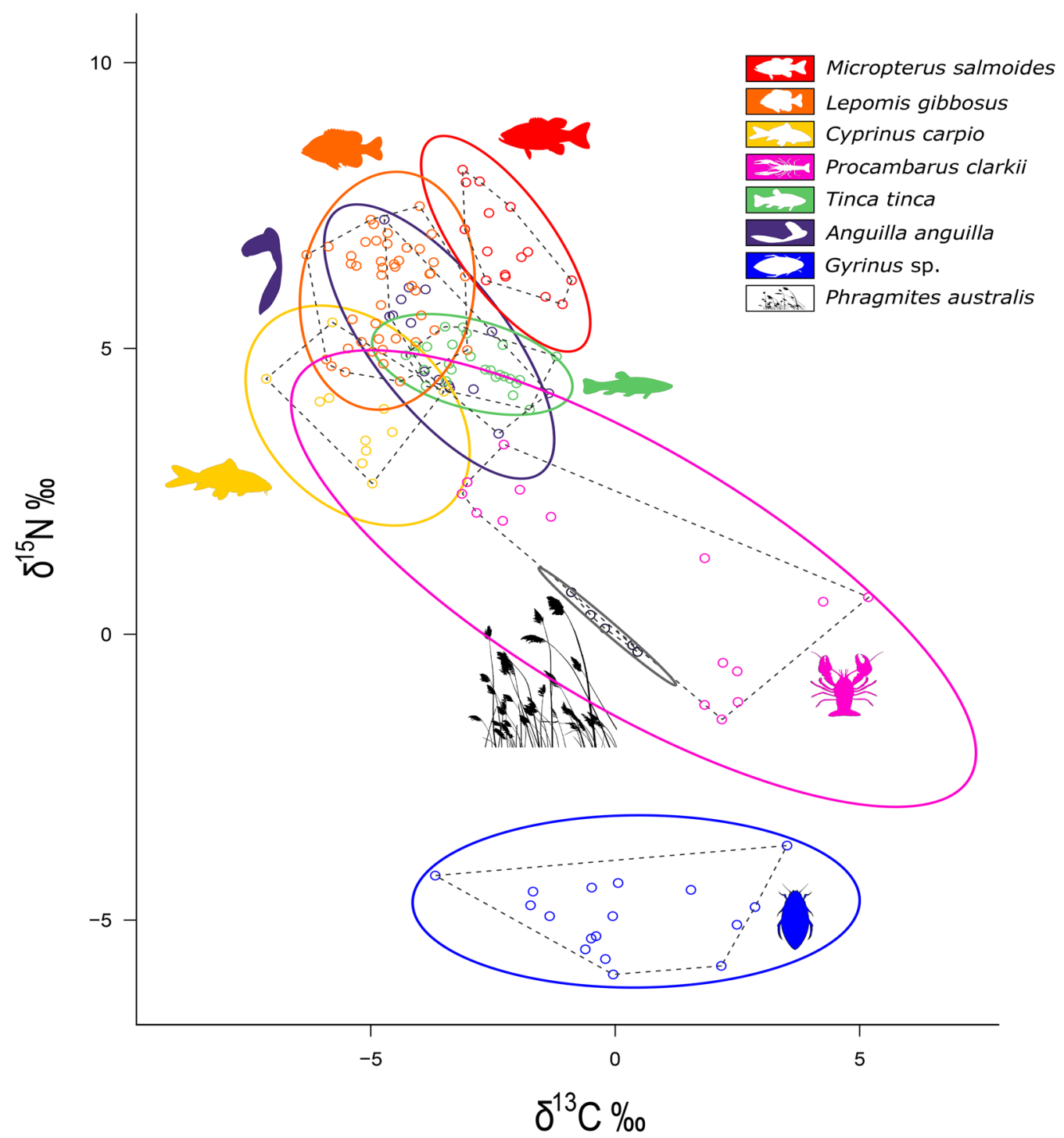

Figure 1.. Isotopic niches of non-native species present in Arreo Lake and the as present assumed native T. tinca and Gyrinus sp.. Solid line = 95\% Standard Ellipse Area (SEAb); dashed line = Total Hull Area (TA); blue: Gyrinus sp.; brown: Phragmites australis; pink: Procambarus clarkii; yellow: Cyprinus carpio; orange: Lepomis gibbosus; green: Tinca tinca; purple: Anguilla anguilla; red: Micropterus salmoides.

\section{Discussion}

In our study, we used highly variable stable isotope data, making our analyses subject to some degree of uncertainty. However, our main aim was to provide a novel theoretical framework to help predict trophic interactions that are no more ongoing due to species extirpations. Combining stable isotope data from different locations relies on the assumption that the trophic niche of a species is conservative ${ }^{40}$. Hence, to make trophic levels comparable, it is essential to scale isotopic data with the local baseline, which can show substantial spatial variation ${ }^{34}$. Second, although the trophic niche could vary (especially for generalist species) depending on the availability of different resources and the community composition or structure in different areas, the approach used here follows the thinking-scheme of all existing risk assessments made for potentially invasive species, i.e. the assumption that it is valid to project species' information (e.g. impacts and behavioural or biological traits) from one area onto another ${ }^{16,19}$. Currently used risk assessment protocols include not only a value for the species-specific risk or impact potential, but also a 'certainty' statement (e.g. low, medium, and high ${ }^{16}$ ). In our approach, it must be considered that the proposed method and risk assessment method focuses only on potentially arising biological interactions, thus neglecting the potential of abiotic changes. Hence, a degree of 'certainty' can be obtained $a$ priori, by utilising stable isotope data from the most similar communities available in terms of species composition (i.e. potential prey populations), structure (i.e. potential competitors and predators), as well as climatic regions, ecosystem type and habitat carrying capacity. Moreover, the present approach can be replicated for various scenarios if the ecosystem from which a species' isotope information is extracted has data from a common 


\begin{tabular}{|c|c|c|c|}
\hline & SEAb overlap & \% isotopic niche overlap (\%) & Probability of overlap (\%) \\
\hline \multicolumn{4}{|l|}{ T. tinca } \\
\hline \multicolumn{4}{|c|}{ Non-native species } \\
\hline M. salmoides & 0.01 & 0.1 & 2.9 \\
\hline L. gibbosus & 4.72 & 33.8 & 89.4 \\
\hline C. carpio & 1.36 & 4.3 & 12.6 \\
\hline P. clarkii & 2.75 & 7.4 & 32.6 \\
\hline \multicolumn{4}{|l|}{ A. anguilla } \\
\hline \multicolumn{4}{|l|}{ Species } \\
\hline M. salmoides & 0.82 & 4.4 & 2.9 \\
\hline L. gibbosus & 7.47 & 42.0 & 70.4 \\
\hline C. carpio & 3.88 & 17.2 & 21.0 \\
\hline P. clarkii & 2.59 & 3.7 & 12.1 \\
\hline \multicolumn{4}{|l|}{ Gyrinus sp. } \\
\hline \multicolumn{4}{|l|}{ Species } \\
\hline M. salmoides & 0.00 & $<0.1$ & 0 \\
\hline L. gibbosus & 0.00 & $<0.1$ & 0 \\
\hline C. carpio & 0.00 & $<0.1$ & 0 \\
\hline P. clarkii & 0.00 & $<0.1$ & 0 \\
\hline
\end{tabular}

Table 3. SEAb overlap among non-native species in Arreo Lake and T. tinca, A. anguilla, and Gyrinus sp. as well as the probability of $t$ hese to occur in the niche of respective non-native species.

A

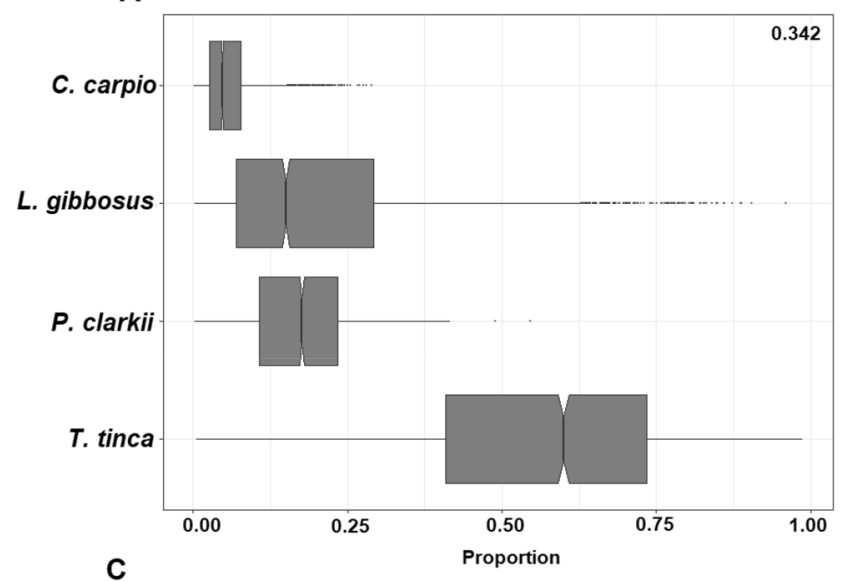

C

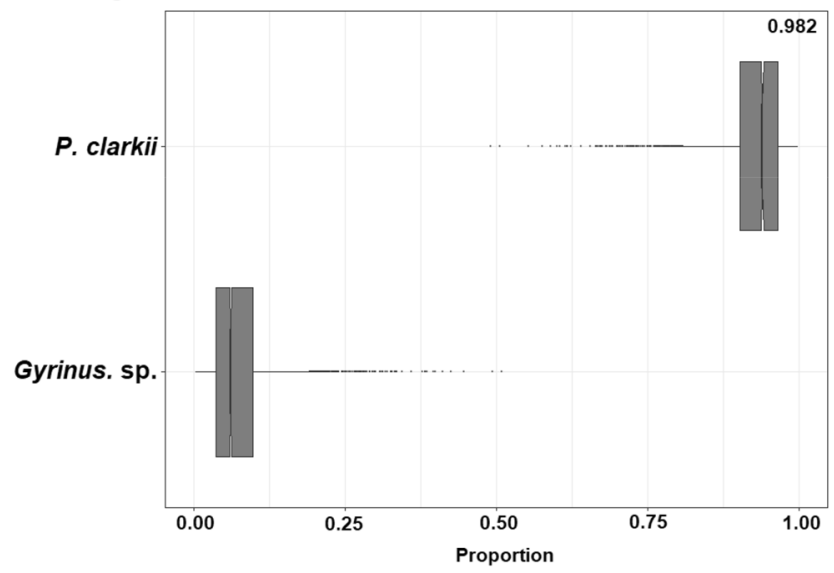

B

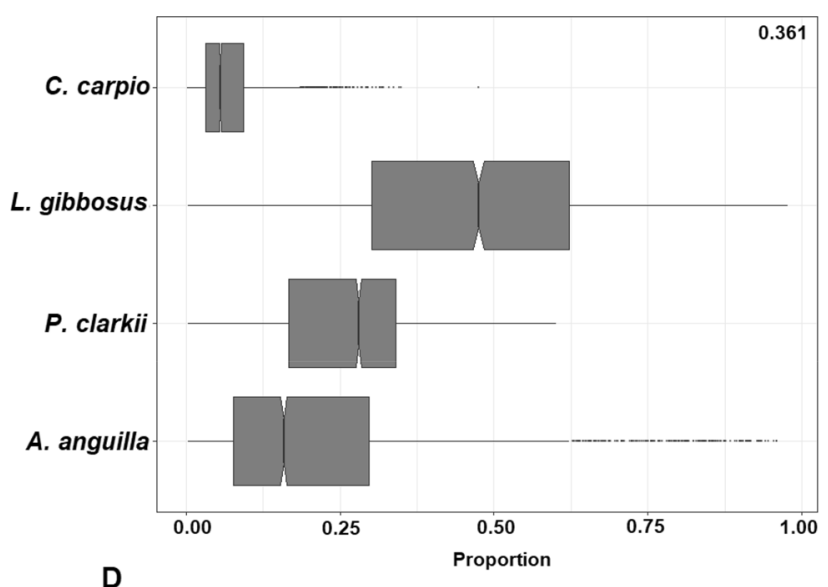

D

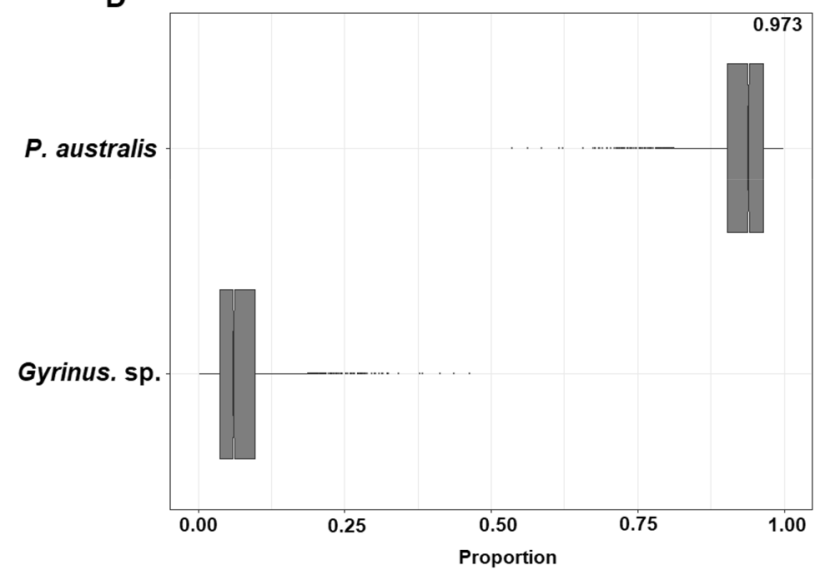

Figure 2.. Mixing models estimated for the respective predatory species: (A) Micropterus salmoides and, Tinca tinca as potentially available prey; (B) Micropterus salmoides under the assumption of present A. anguilla; (C) Lepomis gibbosus assuming that Gyrinus sp. is present in Arreo Lake; and (D) Procambarus clarkii under the assumption of present Gyrinus sp.. Numbers in the upper right corner indicate the estimated probability of the presented prey contribution to the respective predators' isotopic level. 
baseline in the target community. Indeed, this has now been tested successfully both in the present study and in an assessment of the effects of species re-introductions ${ }^{5}$. However, the method can only be considered reliable if biological drivers that could have caused the extirpations of native species are considered with all possible contributing species, and in the absence of abiotic factors. Using more complex systems will likely add higher uncertainties to the estimated results but will still indicate the potential for occurring niche overlap and thus, competition. However, as all risk assessments cannot be free of projected assumptions which may or may not hold true within complex ecosystems due to diverse and unpredictable species interactions, this methodology provides probabilistic estimates, which will correlate with the degree of uncertainty.

Methodological limitations. A notable downside of this approach is the availability of stable isotope data for the relevant species, as for three species only one set of suitable data and for another species no suitable data were found. As a result, data availability can be seen as a key component, while the data from both community and investigated species, ought to be robust. However, even if stable isotope data for target species are found, the comparability to the target community requires testing in relation to the similarity of a common stable isotope baseline, such as filter feeders and primary producers. Without such a comparable baseline, data usability will be characterized by a considerable degree of uncertainty. Moreover, the lack of such comparable baselines as well as the continuous change within ecosystems leads to ongoing variation on trophic niches of studied species, an aspect that needs to be considered in the interpretation of estimated results. However, the greatest obstacle will be the limited availability of stable isotope data. We therefore echo the call of Pauli et al. ${ }^{41,42}$ for the importance of a centralized repository for stable isotope data. Another aspect that has to be mentioned is the fact that the tissue samples collected from Arreo Lake are not influenced by any of the native species that we are superimposing on its food web. Therefore the proportion of the diet that the natives contribute to each predator analysed is in reality 0 , while we assume that the simplified food web has a similar trophic height to that of the native condition, so that when we reintroduce the values for the native species they will lie in the same isotopic niche relative to these invasive species as when both were present in the ecosystem.

Biotic pressure and extinction risks. In scenario (a), where we retrospectively estimated that the introduced $M$. salmoides was a potential predator of T. tinca, our findings support other studies on the deleterious impact of invasive $M$. salmoides populations ${ }^{43-46}$. In addition, we identified the potential for dietary resource overlap among T. tinca and L. gibbosus as well as C. carpio. Recent work by Almeida et al. ${ }^{47}$ suggests that L. gibbosus is aggressive towards native Iberian species and hence, potentially also T. tinca. Moreover, considering the presence of $P$. clarkii and L. gibbosus, as well as information of their invasion histories, it is possible that the resource overlap among these species and $T$. tinca resulted in increased competition, due to the likely reduction of algae (due to P. clarkii) and macroinvertebrate prey due to L. gibbosus ${ }^{48}$ and P. clarkii $^{49}$. Another aspect that has to be considered is the possibility of biotic changes and associated indirect effects. Indeed, the presence of $L$. gibbosus and $P$. clarkii could have reduced potential prey for $T$. tinca (especially molluscs) and aquatic vegetation (amplified by the positive effect of C. carpio on turbidity ${ }^{50}$ ) in shallow areas needed for reproduction ${ }^{51}$.

In the case of Gyrinus sp., mixing models indicated that neither P. clarkii nor L. gibbosus are a major predator, indicating a potential problem with the used baseline while simultaneously indicating the belonging of Gyrinus sp. to a non-aquatic trophic pathway. However, especially in very shallow (depths of few $\mathrm{cm}$ ) but vegetated zones, (i.e. the habitat occupied by both species ${ }^{52,53}$, predation by both P. clarkii and L. gibbosus on especially larval stages of Gyrinus sp. is possible ${ }^{48,54}$. It should be noted that L. gibbosus commonly exerts a more bottom and water column orientated feeding activit ${ }^{55}$. Additionally, as the flying insect abundance potentially decreased due to the decreasing abundance of native flora and increasing abundance of $P$. australis ${ }^{56,57}$, a lack of potential prey might have aided the decline of Gyrinus sp. ${ }^{58,59}$. As a result, considering the high abundance of invasive species in Arreo Lake in the past, possible substantial stressors were (a) feeding pressure, (b) competition for declining resources, as well as (c) bioengineering activities that alter the suitability for reproduction.

Multiple stressors contributing to the demise of native species have been reported for communities of different sizes and structures ${ }^{60,61}$. With the proposed approach, we could show clear indications of biotic interactions, mostly predation and competition, both potentially affecting the native species. While a considerable uncertainty must be accepted, the observed outcomes also indicate direct (e.g. through resource overlap) and indirect effects (e.g. the demise of potential prey) that could have led to the demise of native species. Accordingly, especially the habitat engineering activity of $P$. clarkii ${ }^{62}$ and $C$. carpio ${ }^{63,64}$, thus also the changing vegetation, could have led to substantial alterations that negatively affected suitable reproduction habitat for T. tinca and decreased prey abundance of Gyrinus sp.. As such, in the case of T. tinca and Gyrinus sp., it is probable that a combination of direct and indirect biotic stressors led to the demise of both species.

Evaluating reintroduction opportunities. Management efforts to control non-native species are common practice ${ }^{65,66}$ and should be considered prior to any reintroduction attempts ${ }^{67,68}$. Such management actions aim towards the recovery of native species populations and restoration of habitats ${ }^{67}$. In Arreo Lake, these efforts already led to a considerable decline in non-native species abundance ${ }^{5}$. Using our proposed approach from scenario (b), we argue that in the case of Gyrinus sp., this would mean a decrease in the abundance of the invasive species P. clarkii and L. gibbosus, but also a recovery of natural vegetation and consequently, terrestrial insects in the proximity of Arreo Lake that could be predated by Gyrinus sp.. Additionally, the extinction of Gyrinus sp. likely led to a shortening of the trophic chain, leading to a simplification of the community structure, so that its recovery could favour other species. For T. tinca, recovery could be obtained through the removal of its main predator M. salmoides. Furthermore, its recovery could be facilitated with the retrieval of the aquatic habitat structure that was bioengineered by $P$. clarkii but is needed for reproduction. Reducing all biotic stress- 
ors (competition, predation, lack of suitable prey or habitat required for reproduction, etc.) will improve the chances of a successful recovery of native species and should therefore be the main aim for future management efforts in Arreo Lake. Being a protected habitat, angling activities in Arreo Lake are nowadays strictly forbidden, however, declining populations of $A$. anguilla are a pressing issue ${ }^{69,70}$. The reintroduction and use of $A$. anguilla as biocontrol agent was proposed by Benndorf ${ }^{71}$ and Aquiloni et al. ${ }^{72}$. Haubrock et al. ${ }^{33}$ tested the use of stable isotopes to predict the impact of introducing predatory eels on the non-native species community in Arreo Lake as described in scenario (b). In that study, they indicated that despite seasonal variation in feeding activity, $A$. anguilla would predate both L. gibbosus and P. clarkii. Nevertheless, a moderate predation by M. salmoides on eels was found to be likely, in concordance with the feeding behaviour of M. salmoides ${ }^{73}$. Additionally, it is likely that M. salmoides might function as a competitor for eels ${ }^{74}$, as indicated by its wide feeding behaviour and wide trophic niche ${ }^{75}$. Accordingly, other possibilities that have led to the extinction of A. anguilla must be considered, as such, overfishing ${ }^{69}$ and the closure of the reproductive migration through dams ${ }^{76,77}$. Consequently, the recovery of $A$. anguilla is strictly dependent also by the construction of comeback ladders.

Conclusion. Our approach can be used from both a scientific and a management perspective to inform risk-based management programmes and by contributing to knowledge on invasion impact assessments. Particularly by being aware of potential biological drivers of impact, it helps unravelling the mechanisms behind the declines of native species, while future reintroduction projects may profit from such insights by better estimating the success rate of native species to recover. The application of stable isotope mixing models and bi-plots allow predictions of the importance of biotic stressors and, from a management perspective, enables practical actions. Further research should examine whether the reduction of non-native populations in aquatic systems could be sufficient to enable the recovery of endangered target species, by mediating predation and interspecific competition, as indicated by the presented stable isotopes approach. Furthermore, this method could potentially be applied to other more complex communities and ecosystems to aid in invasive species prioritization by managers or inform control efforts to enable the recovery of native or endangered species. It also provides potential for testing aspects of relevant trophic niche theory relating to biological invasions (e.g. ${ }^{78,79}$ ), promoting the use of extant data rather than designing and completing new experiments.

\section{Methods}

Study site. Arreo Lake covers $1.36 \mathrm{~km}^{2}$ and is situated $655 \mathrm{~m}$ above sea level. As part of the Ebro river basin, it is considered the only natural lake in Basque Country, Northern Spain ${ }^{37}$. The southern areas of the lake are shallow ${ }^{80}$, while on the north side a basin with a steep slope and a depth of $24 \mathrm{~m}$ is located. Arreo Lake is peculiar, as it is naturally fed by hypersaline water from the diapiric substratum $\left(1307-1608 \mu \mathrm{S} / \mathrm{cm}^{37,81}\right)$, which has resulted in the emergence of a unique ecological community. Indeed, Arreo Lake has previously provided habitat to various endemic invertebrate species and a unique species assemblage ${ }^{82}$. However, today, Arreo Lake hosts a very simplified community composed by only non-native species, namely three fish species and one crayfish (Table 1). Similarly, the native flora, of which six species were considered endangered, has been entirely replaced by dense populations of the non-native macrophyte Phragmites australis and the less abundant Cladium mariscus ${ }^{5}$.

Data collection. To test our approach, stable isotope data from the currently existing community in Arreo Lake and the extirpated native species of interest were collected. For the six non-native species (Table 1), stable isotope data (nitrogen $\left[\delta^{15} \mathrm{~N}\right]$ and carbon $\left[\delta^{13} \mathrm{C}\right]$ ) were collected recently (September $2017^{33}$ ). We selected the following four native species that were recently extirpated from Arreo Lake, namely A. anguilla, T. tinca, A. pallipes and Gyrinus sp. (LIFE TREMEDAL project LIFE11 NAT/ES/ 000707; ES2110007). As these species were extirpated, their isotope data could not be collected from Arreo Lake nor individuals from the lake were present in museum collections and therefore, was retrieved from the literature. To identify such potentially suitable stable isotope data for these extirpated native species, we used the ISI Web of Science platform (https://webofknowl edge.com/), Google Scholar (https://scholar.google.com/), the Google search engine (https://www.google.com/) and through contacts with experts. Hence, data availability was considered as the first criterion, followed by data suitability. Documents identified as potentially relevant were thoroughly assessed. Then, it was ensured that the tissue type for fish and crayfish (caudal muscle) and plants (leaves) was consistent, while trying to obtain data from the same seasonal period.

When further selecting data sources for the extirpated native species to be superimposed on the extant nonnative species community, a common baseline organism (i.e. a species that can be used as a reference point to estimate the trophic position of species at higher trophic levels in the food web) must occur in both ecosystems. The suitability and comparability of the baseline organism was determined on the basis of similar ranges $(95 \%$ confidence interval) in $\delta^{15} \mathrm{~N}$ and $\delta^{13} \mathrm{C}$ in both ecosystems. If available, this baseline was then used to standardize the stable isotope data from the community and target species. The data identified as suitable is listed in Table 4 . For T. tinca and A. anguilla, this was accomplished using the macrophyte $P$. australis from either respective community. Note that macrophytes were chosen as the isotopic baseline due to the lack of other commonly used baselines, such as gastropods or filter feeders ${ }^{81}$, in Arreo Lake. The use of macrophyte isotope signatures can be problematic, as this group tends to demonstrate variability between seasons, watersheds, nutrient levels, depth, and even tissue in combination with relatively rapid turnovers. However, we argue that the use of pooled samples, i.e. the combination of leaf tissue from minimum five individual plants per site into one sample in combination with a sufficiently large sample that covers the entire ecosystem while expressing inherently low spatial and temporal variability can be sufficient for a proximate analysis of communities. Further, $P$. australis is less prone to express highly spatially or temporally variable trophic shifts as variations are mostly linked to ambient changes 


\begin{tabular}{|c|c|c|c|c|c|c|c|}
\hline Species & Country & Location & $\begin{array}{l}\text { Stable isotope data } \\
\text { origin }\end{array}$ & $\mathbf{n}$ & Mean $\delta^{15} \mathrm{~N}+$ range [\%o] & Mean $\delta^{13} \mathrm{C}+$ range [\%o] & Tissue type \\
\hline Tinca tinca & England & Small ponds & 88 & 26 & $4.7(3.9-5.4)$ & $-2.9(-4.3$ to -1.2$)$ & Caudal muscle \\
\hline Anguilla anguilla & Germany & $\begin{array}{l}\text { Lake ecosystem Großer } \\
\text { Vätersee }\end{array}$ & 89 & 45 & $6.0(4.4-7.5)$ & $-4.7(-6.3$ to -3.0$)$ & Caudal muscle \\
\hline Austropotamobius pallipes & - & - & - & - & - & - & Tail muscle \\
\hline Gyrinus sp. & Canada & $\begin{array}{l}\text { Experimental Lake area } \\
\text { in Western Ontario }\end{array}$ & 85 & 17 & $-4.9(-6.0$ to -3.8$)$ & $0.2(-3.6$ to 3.6$)$ & Whole organism \\
\hline Micropterus salmoides & \multirow{6}{*}{ Spain } & \multirow{6}{*}{$\begin{array}{l}\text { Arreo Lake in Basque } \\
\text { country }\end{array}$} & \multirow{6}{*}{33} & 15 & $6.8(5.8-7.9)$ & $-2.2(-3.1$ to -0.9$)$ & Caudal muscle \\
\hline Cyprinus carpio & & & & 11 & $3.8(2.6-5.5)$ & $-5.3(-7.1$ to -3.5$)$ & Caudal muscle \\
\hline Lepomis gibbosus & & & & 15 & $5.1(3.5-7.3)$ & $-3.6(-4.7$ to 1.4$)$ & Caudal muscle \\
\hline Procambarus clarkii & & & & 15 & $1.0(-1.5$ to 3.3$)$ & $0.4(-3.1$ to 5.2$)$ & Tail muscle \\
\hline Phragmites australis & & & & 5 & $0.0(-0.4$ to 0.6$)$ & $-0.0(-0.7$ to 0.6$)$ & $5 \times 5$ pooled leaf samples \\
\hline Cladium mariscus & & & & \multicolumn{4}{|c|}{ Not sampled } \\
\hline
\end{tabular}

Table 4. Origin and ranges of finally considered stable isotope data after standardization by subtracting the communities' respective baseline.

in salinity which are generally not strongly fluctuating in isolated lakes ${ }^{83,84}$. Hence, it should be sufficient for the momentary analysis and first step in this novel application as proposed here.

For Gyrinus sp. only one potentially suitable study was identified ${ }^{85}$, as the number of specimens reported from other studies (e.g. ${ }^{86} ; n=3$ ) was too low. Despite the lack of any comparable baseline organisms (e.g. macrophytes) or other occurring species between both Kullman et al. ${ }^{85}$ and Arreo Lake, comparability of stable isotope data was accepted under the assumption that species in lower trophic positions like Gyrinus sp. express lower degrees of niche variability among different populations due to limited isotopic variability in their potential prey compared to species in higher trophic positions ${ }^{87}$. In this case, we selected the standardization with the Arreo Lake macrophyte, assuming it to be a valid alternative. In the case of $A$. pallipes, no stable isotope data was found, likely due to its protected status and limited distribution. This was also true for the ecologically similar and closely related stone crayfish $A$. torrentium.

Suitable stable isotope data were complemented with information on the biology, ecology and dietary data of the respective species (Supplement 1). Due to lack of suitable stable isotope data for A. pallipes, information on dietary preferences and impacts were reviewed only for Gyrinus sp., T. tinca, A. anguilla and the non-native species present in Arreo Lake. For these species, results from the literature reviews were combined with stable isotope data for the non-native species from Arreo Lake to reconstruct their interactions and thus their ecological impacts. All stable isotope data that were used are presented in Supplement 2.

Data analysis. Standardization of isotope data $\left(\delta^{15} \mathrm{~N}\right.$ and $\left.\delta^{13} \mathrm{C}\right)$ was performed for all species in Arreo Lake as well as for the values extracted for extirpated native species according to Haubrock et al. ${ }^{33}$ by subtracting the populations specific baselines' mean value for $\delta^{15} \mathrm{~N}$ and $\delta^{13} \mathrm{C}$, respectively, to make isotopic data comparable (Table 2). Then, both data arrays of the target community and the introduced species were combined.

To compare ecological roles of the once native T. tinca and Gyrinus sp. in contrast to the non-native species present in Arreo Lake, the trophic position for each species was estimated. This was done using the R package "tRophicPosition", which uses Markov Chain Monte Carlo simulations ${ }^{90}$. Because trophic discrimination factors (TDFs) were not available for all species, we included simulated tissue discrimination factors from Post ${ }^{34}$ using the R function 'simulateTDF.tRophicPosition's0.

To quantify isotopic niches and identify changes in the isotopic community structure following the respective decline of T. tinca and Gyrinus sp., Layman's metrics were calculated ${ }^{91,92}$ for each species individually as well as for the community with and without it. Layman's metrics describe the isotopic niche dimensions of a species or a community, while the isotopic niche is the trophic space of a species which is affected by e.g. growth and metabolism or isotopic turnover and defined by individual points in a two-dimension isotopic space ${ }^{91}$.

Moreover, the Bayesian standardized ellipse areas (SEAc: alpha $=0.4$; SEAb: alpha $=0.95$ ), which encompass a sampled population in a $\delta^{15} \mathrm{~N} / \delta^{13} \mathrm{C}$ bi-plot space and thus serves as measures of core niche space, as well as the proportion of overlap in the isotopic niches ${ }^{92}$, were calculated in the R package "SIBER" 26 . These estimated the isotopic niche overlaps among the species currently present in Arreo Lake and the extirpated T. tinca and Gyrinus sp., therefore indicating potentially competitive interactions. Additionally, the R package "NicheRover" was used to calculate the directional pairwise probability of either targeted species occurring within the niche of other species from Arreo Lake. This approach utilizes a Monte Carlo estimation (chain length: 20.000 steps), computing the probability of the niche of species ' $\mathrm{A}$ ' to overlap onto the niche of species ' $\mathrm{B}$ '93, therefore highlighting potentially occurring niche overlap.

Lastly, to investigate predation as a cause of extinction, mixing models as part of the R package "simmr" 32 were employed. The application of mixing models relies on the use of dual plot graphs for $\delta^{15} \mathrm{~N}$ and $\delta^{13} \mathrm{C}$, enabling assumptions on probable prey sources and combinations of prey contributing to the diet of consumers. Hence, mixing models were employed for predatory species that could consume native species on the assumption that predation occurs on lower trophic levels due to $\delta^{15} \mathrm{~N}$ increments across trophic levels. Only one native species was included in the community at once to determine the pathway that is the major source of energy as both T. tinca 
and Gyrinus sp. belong to different energy pathways (i.e. terrestrial versus aquatic). Including both together could lead to a meaningless confounding effect. Further, mixing models were presented with the estimated probability of each scenario, i.e. the likeliness of the identified prey contributing to the respective predators' isotopic level.

Received: 6 August 2020; Accepted: 23 November 2020

Published online: 10 December 2020

\section{References}

1. Lovell, S. J., Stone, S. F. \& Fernandez, L. The economic impacts of aquatic invasive species: a review of the literature. Agric. Resour. Econ. Rev. 35(1), 195-208 (2006).

2. Ehrenfeld, J. G. Ecosystem consequences of biological invasions. Ann. Rev. Ecol. Evol. Syst. 41, 59-80 (2010).

3. Dunham, J. B., Adams, S. B., Schroeter, R. E. \& Novinger, D. C. Non-native invasions in aquatic ecosystems: toward an understanding of brook trout invasions and potential impacts on inland cutthroat trout in western North America. Rev. Fish Biol. Fish. 12(4), 373-391 (2002).

4. Balzani, P. et al. Stable isotope analysis of trophic niche in two co-occurring native and invasive terrapins, Emys orbicularis and Trachemys scripta elegans. Biol. Invasions 18(12), 3611-3621 (2016).

5. Haubrock, P. J. et al. Control and eradication efforts of aquatic non-native fish species in Lake Caicedo Yuso-Arreo. Manag. Biol. Invasions 9, 267-278 (2018).

6. Preston, D. L., Henderson, J. S. \& Johnson, P. T. Community ecology of invasions: direct and indirect effects of multiple invasive species on aquatic communities. Ecology 93(6), 1254-1261 (2012).

7. Gallardo, B., Clavero, M., Sánchez, M. I. \& Vilà, M. Global ecological impacts of invasive species in aquatic ecosystems. Glob. Change Biol. 22(1), 151-163 (2016).

8. Pejchar, L. \& Mooney, H. A. Invasive species, ecosystem services and human well-being. Trends Ecol. Evol. 24(9), 497-504 (2009).

9. Simberloff, D. \& Von Holle, B. Positive interactions of nonindigenous species: invasional meltdown?. Biol. Invasions 1(1), 21-32 (1999).

10. Beisel, J. N. The elusive model of a biological invasion process: time to take differences among aquatic and terrestrial ecosystems into account? (2001).

11. Ricciardi, A. \& Cohen, J. The invasiveness of an introduced species does not predict its impact. Biol. Invasions 9(3), 309-315 (2007).

12. Strayer, D. L. Non-native species in fresh waters: ecological effects, interactions with other stressors, and prospects for the future. Freshw. Biol. 55, 152-174 (2010).

13. Früh, D., Stoll, S. \& Haase, P. Physicochemical and morphological degradation of stream and river habitats increases invasion risk. Biol. Invasions 14(11), 2243-2253 (2012).

14. Höckendorff, S., Früh, D., Hormel, N., Haase, P. \& Stoll, S. Biotic interactions under climate warming: temperature-dependent and species-specific effects of the oligochaete Chaetogaster limnaei on snails. Freshw. Sci. 34, 1304-1311 (2015).

15. Leung, B. \& Mandrak, N. E. The risk of establishment of aquatic invasive species: joining invasibility and propagule pressure. Proc. R. Soc. B Biol. Sci. 274(1625), 2603-2609 (2007).

16. Copp, G. H., Garthwaite, R. \& Gozlan, R. E. Risk identification and assessment of non-native freshwater fishes: a summary of concepts and perspectives on protocols for the UK. J. Appl. Ichthyol. 21(4), 371-373 (2005).

17. Copp, G. H. et al. European non-native species in aquaculture risk analysis scheme-a summary of assessment protocols and decision support tools for use of non-native species in aquaculture. Fish. Manag. Ecol. 23(1), 1-11 (2016).

18. Bacher, S. et al. Socio-economic impact classification of non-native taxa (SEICAT). Methods Ecol. Evol. 9(1), 159-168 (2018).

19. Roy, H. E. et al. Developing a framework of minimum standards for the risk assessment of non-native species. J. Appl. Ecol. 55(2), 526-538 (2018).

20. Moustakas, A. \& Katsanevakis, S. Data mining and methods for early detection, horizon scanning, modelling, and risk assessment of invasive species. Front. Appl. Math. Stat. 4, 5 (2018).

21. Dick, J. T. et al. Invader relative impact potential: a new metric to understand and predict the ecological impacts of existing, emerging and future invasive non-native species. J. Appl. Ecol. 54(4), 1259-1267 (2017).

22. Cuthbert, R. N., Dickey, J. W., Coughlan, N. E., Joyce, P. W. \& Dick, J. T. The functional response ratio (FRR): advancing comparative metrics for predicting the ecological impacts of invasive non-native species. Biol. Invasions 1-5 (2019).

23. Haubrock, P. J. et al. Predatory functional responses under increasing temperatures of two life stages of an invasive gecko. Sci. Rep. 10(1), 1-10(2020).

24. Vonesh, J., McCoy, M., Altwegg, R., Landi, P. \& Measey, J. Functional responses can't unify invasion ecology. Biol. Invasions 19(5), 1673-1676 (2017).

25. Dick, J. T. et al. Fictional responses from Vonesh et al. Biol. Invasions 19(5), 1677-1678 (2017)

26. Vander Zanden, M. J., Casselman, J. M. \& Rasmussen, J. B. Stable isotope evidence for the food web consequences of species invasions in lakes. Nature 401(6752), 464 (1999).

27. Haubrock, P. J. et al. Shared histories of co-evolution may affect trophic interactions in a freshwater community dominated by non-native species. Front. Ecol. Evol. 7, 355 (2019).

28. Stellati, L. et al. Living with non-natives: suboptimal ecological condition in semiaquatic snakes inhabiting a hot spot of allodiversity. Acta Oecol. 100, 103466 (2019).

29. Huckembeck, S. et al. Feeding ecology and basal food sources that sustain the Paradoxal frog Pseudis minuta: a multiple approach combining stomach content, prey availability, and stable isotopes. Hydrobiologia 740(1), 253-264 (2014).

30. Middelburg, J. J. Stable isotopes dissect aquatic food webs from the top to the bottom. Biogeosciences. 11, 2357-2371 (2014).

31. Jackson, A. L., Inger, R., Parnell, A. C. \& Bearhop, S. Comparing isotopic niche widths among and within communities: SIBERstable isotope bayesian ellipses in R. J. Anim. Ecol. 80(3), 595-602 (2011).

32. Parnell, A. C. et al. Bayesian stable isotope mixing models. Environmetrics 24(6), 387-399 (2013).

33. Haubrock, P. J. et al. Predicting the effects of reintroducing a native predator (European eel, Anguilla anguilla) into a freshwater community dominated by non-native species using a multidisciplinary approach. Manag. Biol. Invasions 10(1), 171-191 (2019).

34. Post, D. M. Using stable isotopes to estimate trophic position: models, methods, and assumptions. Ecology 83(3), 703-718 (2002).

35. Füreder, L., Gherardi, F., Holdich, D., Reynolds, J., Sibley, P. \& Souty-Grosset, C. Austropotamobius pallipes. The IUCN Red List of Threatened Species. e.T2430A9438817. https://doi.org/10.2305/IUCN.UK.2010-3.RLTS.T2430A9438817.en. (2010).

36. Pike, C., Crook, V. \& Gollock, M. Anguilla anguilla. The IUCN Red List of Threatened Species e.T60344A152845178. https://doi. org/10.2305/IUCN.UK.2020-2.RLTS.T60344A152845178.en. (2020).

37. González-Mozo, M. E., Chicote, A., Rico, E. \& Montes, C. Limnological characterization of an evaporite karstic lake in Spain (Arreo Lake). Trends Ecol. Evol. 19(9), 470-474 (2004).

38. Asensio, R. Actuaciones de descaste de cangrejos alóctonos en el lago de Caicedo Yuso - Arreo para los años 2014 y 2015. PROYECTO TREMEDAL “LIFE11 NAT/ES/707”. URA/Arabako Foru Aldundia/HAZI. (2015). 
39. Alonso de Santocildes, G., Criado, A., Manzanos, A. \& A.P. Monteoliva. Fish sampling in inland lakes: methodological approach and case study, Arreo Lake (Álava). IV Jornadas Ibéricas de Ictiología (2012).

40. Losos, J. B. Phylogenetic niche conservatism, phylogenetic signal and the relationship between phylogenetic relatedness and ecological similarity among species. Ecol. Lett. 11(10), 995-1003 (2008).

41. Pauli, J. N., Steffan, S. A. \& Newsome, S. D. It is time for IsoBank. BioScience 65(3), 229-230 (2015).

42. Pauli, J. N. et al. Opinion: Why we need a centralized repository for isotopic data. Proc. Natl. Acad. Sci. 114(12), 2997-3001 (2017).

43. Gratwicke, B. \& Marshall, B. E. The relationship between the exotic predators Micropterus salmoides and Serranochromis robustus and native stream fishes in Zimbabwe. J. Fish Biol. 58(1), 68-75 (2001).

44. Maezono, Y. \& Miyashita, T. Community-level impacts induced by introduced largemouth bass and bluegill in farm ponds in Japan. Biol. Conserv. 109(1), 111-121 (2003).

45. Yonekura, R., Kita, M. \& Yuma, M. Species diversity in native fish community in Japan: comparison between non-invaded and invaded ponds by exotic fish. Ichthyol. Res. 51(2), 176-179 (2004).

46. Maezono, Y., Kobayashi, R., Kusahara, M. \& Miyashita, T. Direct and indirect effects of exotic bass and bluegill on exotic and native organisms in farm ponds. Ecol. Appl. 15(2), 638-650 (2005).

47. Almeida, D., Gomes-Lopes, A., Muñoz-López, M., Merino-Aquirre, R. \& Miranda, R. Ecología de la agresión interespecífica en el pez sol Lepomis gibbosus y efectos sobre la fauna autóctona. In Posters from the Symposium on non-native freshwater species introduction in the Iberian Peninsula, Pamplona, Spain. http://www.unav.es/centro/especiesinvasoras/ (2009).

48. Froese, R., \& Pauly, D. (2010). www.FishBase.de. Accessed November 19th, 2019.

49. Oficialdegui, F. J., Sánchez, M. I. \& Clavero, M. One century away from home: how the red swamp crayfish took over the world. Rev. Fish Biol. Fish. 1-15 (2020).

50. Fletcher, A. R., Morison, A. K. \& Hume, D. J. Effects of carp, Cyprinus carpio L., on communities of aquatic vegetation and turbidity of waterbodies in the lower Goulburn River basin. Mar. Freshw. Res. 36(3), 311-327 (1985).

51. Pompei, L., Franchi, E., Giannetto, D. \& Lorenzoni, M. Growth and reproductive properties of Tench, Tinca tinca Linnaeus, 1758 in Trasimeno Lake (Umbria, Italy). Knowl. Manag. Aquat. Ecosyst. 406 (2012).

52. Angeler, D. G., Sánchez-Carrillo, S., García, G. \& Alvarez-Cobelas, M. The influence of Procambarus clarkii (Cambaridae, Decapoda) on water quality and sediment characteristics in a Spanish floodplain wetland. Hydrobiologia 464(1-3), 89-98 (2001).

53. Jastrebski, C. J. \& Robinson, B. W. Natural selection and the evolution of replicated trophic polymorphisms in pumpkinseed sunfish (Lepomis gibbosus). Evol. Ecol. Res. 6(2), 285-305 (2004).

54. Gherardi, F. \& Barbaresi, S. Feeding opportunism of the red swamp crayfish Procambarus clarkii, an invasive species. Freshw. Crayfish 16, 77-85 (2008).

55. Wolfram-Wais, A., Wolfram, G., Auer, B., Mikschi, E. \& Hain, A. Feeding habits of two introduced fish species (Lepomis gibbosus, Pseudorasbora parva) in Neusiedler See (Austria), with special reference to chironomid larvae (Diptera: Chironomidae). Shallow Lakes 98, 123-129 (1999).

56. Fell, P. E. et al. Does invasion of oligohaline tidal marshes by reed grass, Phragmites australis (Cav.) Trin. ex Steud., affect the availability of prey resources for the mummichog, Fundulus heteroclitus L.? J. Exper. Mar. Biol. Ecol. 222(1-2), 59-77 (1998).

57. Bedford, A. P. \& Powell, I. Long-term changes in the invertebrates associated with the litter of Phragmites australis in a managed reedbed. Hydrobiologia 549(1), 267-285 (2005).

58. Chambers, R. M., Meyerson, L. A. \& Saltonstall, K. Expansion of Phragmites australis into tidal wetlands of North America. Aquat. Bot. 64(3-4), 261-273 (1999).

59. Gratton, C. \& Denno, R. F. Restoration of arthropod assemblages in a Spartina salt marsh following removal of the invasive plant Phragmites australis. Restoration Ecology. 13(2), 358-372 (2005).

60. Gherardi, F. et al. A review of allodiversity in Lake Naivasha, Kenya: developing conservation actions to protect East African lakes from the negative impacts of non-native species. Biol. Conserv. 144(11), 2585-2596 (2011).

61. Stiers, I., Crohain, N., Josens, G. \& Triest, L. Impact of three aquatic invasive species on native plants and macroinvertebrates in temperate ponds. Biol. Invasions 13(12), 2715-2726 (2011).

62. Barbaresi, S., Tricarico, E. \& Gherardi, F. Factors inducing the intense burrowing activity of the red-swamp crayfish, Procambarus clarkii, an invasive species. Naturwissenschaften 91(7), 342-345 (2004).

63. Britton, J. R. et al. From introduction to fishery dominance: the initial impacts of the invasive carp Cyprinus carpio in Lake Naivasha, Kenya, 1999 to 2006. J. Fish Biol. 71, 239-257. https://doi.org/10.1111/j.1095-8649.2007.01669.x (2007).

64. Anton-Pardo, M., Hlaváč, D., Másílko, J., Hartman, P. \& Adámek, Z. Natural diet of mirror andscaly carp (Cyprinus carpio) phenotypes in earth ponds. Folia Zool. 63, 229-237. https://doi.org/10.25225/fozo.v63.i4.a1.2014 (2014).

65. Hauser, C. E. \& McCarthy, M. A. Streamlining 'search and destroy': cost-effective surveillance for invasive species management. Ecol. Lett. 12(7), 683-692 (2009).

66. Rinella, M. J., Maxwell, B. D., Fay, P. K., Weaver, T. \& Sheley, R. L. Control effort exacerbates invasive-species problem. Ecol. Appl. 19(1), 155-162 (2009).

67. Jourdan, J. et al. Reintroduction of freshwater macroinvertebrates: challenges and opportunities. Biol. Rev. 94(2), 368-387 (2019).

68. Haase, P., \& Pilotto, F. A method for the reintroduction of entire benthic invertebrate communities in formerly degraded streams. Limnologica, 77, 125689 (2019).

69. Feunteun, E. Management and restoration of European eel population (Anguilla anguilla): an impossible bargain. Ecol. Eng. 18(5), 575-591 (2002).

70. Clavero, M. \& Hermoso, V. Historical data to plan the recovery of the European eel. J. Appl. Ecol. 52(4), 960-968 (2015).

71. Benndorf, J. Possibilities and limits for controlling eutrophication by biomanipulation. Int. Rev. Hydrobiol. 80, 519-534. https:// doi.org/10.1002/iroh.19950800404 (1995).

72. Aquiloni, L. et al. Biological control of invasive populations of crayfish: the European eel (Anguilla anguilla) as a predator of Procambarus clarkii. Biol. Invasions 12, 3817-3824. https://doi.org/10.1007/s10530-010-9774-z (2010).

73. McCord JW American eel. South Carolina State Documents Depository (2005)

74. Schiphouwer, M. E. et al. Risk assessment of the alien smallmouth bass (Micropterusdolomieu). Rep. Environ. Sci. 527, 1-60 (2017).

75. Costantini, M. L. et al. The role of alien fish (the centrarchid Micropterus salmoides) in lake food webs highlighted by stable isotope analysis. Freshw. Biol. 63, 1130-1142. https://doi.org/10.1111/fwb.13122 (2018).

76. Laffaille, P., Caraguel, J. M. \& Legault, A. Temporal patterns in the upstream migration of European glass eels (Anguilla anguilla) at the Couesnon estuarine dam. Estuarine Coast. Shelf Sci. 73(1-2), 81-90 (2007).

77. Prigge, E. Factors challenging the European eel (Anguilla anguilla) stock recovery in continental waters (Doctoral dissertation, Christian-Albrechts Universität Kiel) (2013).

78. Catford, J. A., Jansson, R. \& Nilsson, C. Reducing redundancy in invasion ecology by integrating hypotheses into a single theoretical framework. Divers. Distrib. 15(1), 22-40 (2009).

79. Marchi, M. et al. Resistance and re-organization of an ecosystem in response to biological invasion: some hypotheses. Ecol. Modell. 222(16), 2992-3001 (2011).

80. Martínez-Torres, L., Gonzáles-Tapia, J. R. \& Ramóm-Luch, C. Batimetría y propuesta de cartografía geológica del lago de Arreo (Diapiro de salinas de Añana, Álava) Eusko Jkaskuntza. Cuadernos de Sección. Historia 20, 123-134 (1992).

81. Camacho, A., Borja, C., Valero-Garcés, B., Sahuquillo, M., Cirujano, S., Soria, J. M., Rico, E., De la Hera, A., Santamans, A. C., García deDomingo, A., Chicote, A. \& Gosálvez, R. U. 3190 Lagos ylagunas kársticas sobre yesos. In: Ministerio de Medio Ambiente,y 
Medio Rural y Marino Bases ecológicas preliminares para laconservación de los tipos de hábitat de interés comunitario en España. Madrid, Spain, $37 \mathrm{pp}$ (2009).

82. Vitoria-Gasteiz, L. Biodiversity Strategy of the Basque Autonomous Community 2030 and First Action Plan 2020; Servicio Central de Publicaciones del Gobierno Vasco (2016).

83. Choi, W. J., Ro, H. M. \& Chang, S. X. Carbon isotope composition of Phragmites australis in a constructed saline wetland. Aquat. Bot. 82(1), 27-38 (2005).

84. Bergamino, L., Dalu, T. \& Richoux, N. B. Evidence of spatial and temporal changes in sources of organic matter in estuarine sediments: stable isotope and fatty acid analyses. Hydrobiologia 732(1), 133-145 (2014).

85. Kullman, M. A., Kidd, K. A., Podemski, C. L., Paterson, M. J. \& Blanchfield, P. J. Assimilation of freshwater salmonid aquaculture waste by native aquatic biota. Can. J. Fish. Aquat. Sci. 66(11), 1965-1975 (2009).

86. Tonn, W. M., Klatt, P. H., Paszkowski, C. A., Gingras, B. A. \& Wilcox, K. Trophic Relations of the Red-Necked Grebe on Lakes in the Western Boreal Forest: A Stable-Isotope Analysis (2004).

87. Jardine, T. D. et al. Understanding and overcoming baseline isotopic variability in running waters. River Res. Appl. 30(2), 155-165 (2014).

88. Tran, T. N. Q., Jackson, M. C., Sheath, D., Verreycken, H. \& Britton, J. R. Patterns of trophic niche divergence between invasive and native fishes in wild communities are predictable from mesocosm studies. J. Anim. Ecol. 84(4), 1071-1080 (2015).

89. Dörner, H. et al. Piscivory and trophic position of Anguilla anguilla in two lakes: importance of macrozoobenthos density. J. Fish Biol. 74(9), 2115-2131 (2009).

90. Quezada-Romegialli, C. et al. tRophicPosition, an R package for the Bayesian estimation of trophic position from consumer stable isotope ratios. Methods Ecol. Evol. 9(6), 1592-1599 (2018).

91. Layman, C. A. et al. Applying stable isotopes to examine food-web structure: an overview of analytical tools. Biol. Rev. 87(3), 545-562 (2012).

92. Layman, C. A., Arrington, D. A., Montaña, C. G. \& Post, D. M. Can stable isotope ratios provide for community-wide measures of trophic structure?. Ecology 88(1), 42-48 (2007).

93. Swanson, H. K. et al. A new probabilistic method for quantifying n-dimensional ecological niches and niche overlap. Ecology $\mathbf{9 6}(2)$, 318-324 (2015).

\section{Acknowledgements}

We wish to thank Alberto Criado and Agustin P. Monteoliva for valuable information on the studied community and prior sampling. We also want to thank Antonín Kouba for his useful comments on the conceptual idea and Ross Cuthbert for proof reading and language editing.

\section{Author contributions}

P.J.H. and P.B. conceived the idea and analysed the data. R.J.B. provided data and insights. P.J.H., P.B., R.J.B. and P.H. wrote the manuscript.

\section{Funding}

Open Access funding enabled and organized by Projekt DEAL.

\section{Competing interests}

The authors declare no competing interests.

\section{Additional information}

Supplementary information is available for this paper at https://doi.org/10.1038/s41598-020-78328-9.

Correspondence and requests for materials should be addressed to P.J.H.

Reprints and permissions information is available at www.nature.com/reprints.

Publisher's note Springer Nature remains neutral with regard to jurisdictional claims in published maps and institutional affiliations.

(c) (i) Open Access This article is licensed under a Creative Commons Attribution 4.0 International License, which permits use, sharing, adaptation, distribution and reproduction in any medium or format, as long as you give appropriate credit to the original author(s) and the source, provide a link to the Creative Commons licence, and indicate if changes were made. The images or other third party material in this article are included in the article's Creative Commons licence, unless indicated otherwise in a credit line to the material. If material is not included in the article's Creative Commons licence and your intended use is not permitted by statutory regulation or exceeds the permitted use, you will need to obtain permission directly from the copyright holder. To view a copy of this licence, visit http://creativecommons.org/licenses/by/4.0/.

(C) The Author(s) 2020 